\title{
A specimen of Canis cf. C. etruscus (Mammalia, Carnivora) from the Middle Villafranchian of the Oosterschelde
}

\author{
J.W.F. Reumer ${ }^{1,2, *}$ \& P. Piskoulis ${ }^{1}$
}

1 University of Utrecht, Department of Earth Sciences, Faculty of Geosciences, Utrecht, the Netherlands

2 Natuurhistorisch Museum Rotterdam, Rotterdam, the Netherlands

* Corresponding author. Email: j.w.f.reumer@uu.nl

Manuscript received: 11 November 2015, accepted: 23 November 2015

\section{Abstract}

A recent find of a Middle Villafranchian (c. 2.35-2.10 Ma) Canis cf. C. etruscus in the trawlings from the Oosterschelde concerns the oldest dog known from the Netherlands and is the first appearance record of this canid in the North Sea Basin. It shows that the tribe Canini was dispersed beyond south central Europe up to the northwestern edge of the continent. The find confirms the lack of synchroneity and usefulness of the so-called 'Wolf Event'.

Keywords: Canis etruscus, 0osterschelde, Villafranchian, Wolf Event

\section{Introduction}

In present-day Europe two members of the genus Canis, the wolf (C. lupus) and the jackal (C. aureus), exist. A similar situation prevailed during much of the Quaternary (e.g. Brugal \& Boudadi-Maligne, 2011), but there has been an ongoing debate on the moment of arrival of the first Canis. In September 2012 the annual Kor \& Bot expedition dredging for fossils in the 0osterschelde estuary resulted, among numerous other finds, in the discovery of a fragmented canid mandible. The 0osterschelde (also known in literature as Eastern Scheldt) is a dammed-off estuary located in the province of Zeeland (the Netherlands) where fossiliferous submarine sediments have been dredged since the 1950s (De Vos et al., 1998; Scager, 2015). The faunal content of the mammalian thanatocoenosis was published by (among others) De Vos et al. (1998) and is now considered to date to the Early Pleistocene, MN17b sensu Palombo \& Valli, 2003-2004; MNR2 sensu Mayhew et al., 2014, c. 2.35 - 2.10 Ma (see Scager, 2015). These fossils were subsequently resedimented in a Late Pleistocene channel lag deposited by the proto-Schelde (Slupik et al., 2013) and are a rare example of a reworked and ex situ faunule that is nonetheless considered as a faunistic entity.
Fossils are fished from the bottom of two deep gullies in the estuary, the Flauwerspolder pits 1 and 2 (formerly called Olifantenputje and Gastenputje; Scager, 2015), both at close distance to the reinforced coast of the island of Schouwen-Duiveland. The fishing depth is c. $35-40 \mathrm{~m}$ (for the techniques used see Mol et al. (1999) and Reumer et al. (2005)). The sediment at that depth lies at the top of the Maassluis Formation and comprises medium- to fine-grained arenite with a small amount of lithic grains or with small particles of clay, manganese and shell fragments (Slupik et al., 2013).

The mandible fragment was easily recognised as belonging to a canid and has now been studied as it immediately raised questions concerning the relationship between the date of the faunule and the supposedly synchronous 'Wolf Event' (e.g. Sardella \& Palombo, 2007; hereafter WE). Carnivores from the Villafranchian 0osterschelde faunule had previously been restricted to Hyaenidae (Pliocrocuta perrieri) and Machairodontidae (Homotherium sp.; Scager, 2015). The find of a canid mandible thus evoked considerable interest. The purpose of this paper is to identify the fragment, provide its description and check its probable relation to the Early Pleistocene WE. The WE was meant to mark the first appearance of the genus Canis in Europe (see Lacombat et al., 2008), in the form of the early 

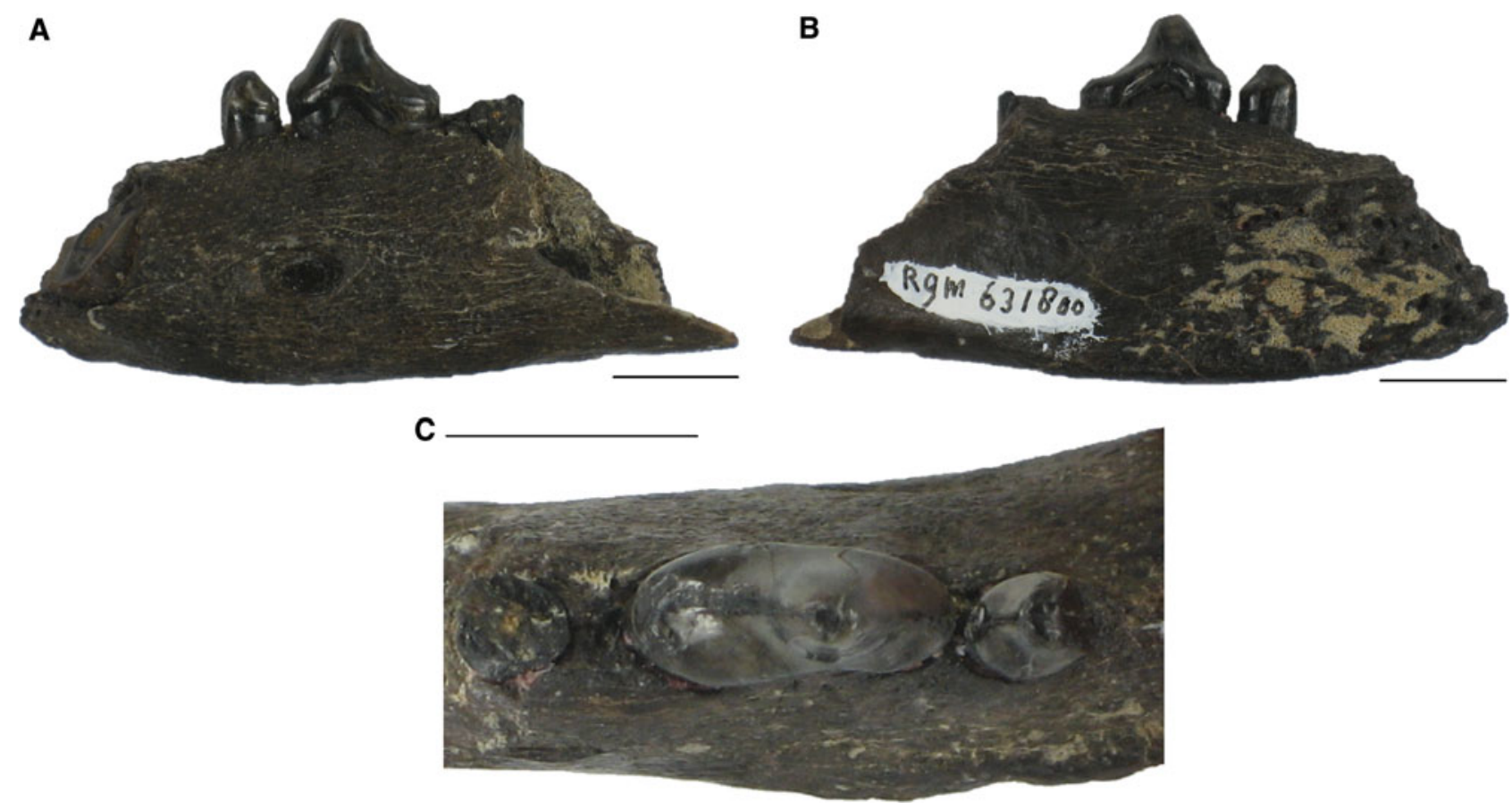

Fig. 1. RGM631800; A. Buccal view; B. Lingual view; C. Dentition in occlusal view. Bar $=10 \mathrm{~mm}$.

wolf C. etruscus, c. 2.0 Ma ago (Cherin et al., 2013). However, quite a few taxa have been described within the genus, the exact status of which is open to debate. In addition, members of the genus were found in sediments of much older date.

\section{Material and methods}

The material was collected using a trawl net designed for commercially trawling edible mussels (Mytilus edulis). For this purpose, the vessel ZZ10 engages in a yearly traditional trawling expedition on the 0osterschelde estuary, trawling in the c. 35$40 \mathrm{~m}$ deep gullies south of the island of Schouwen-Duiveland. The collected bone and dental material is then desalinized (if necessary), conserved and stored. The mandibular fragment studied here consists of part of the left horizontal ramus with two premolars (p1 and p2), part of the canine (c) and part of the third premolar (p3) (see Fig. 1). The mental foramen is visible. It is stored at the National Museum of Natural History (NCB Naturalis), Leiden, under registration number RGM631800. Measurements were taken with a Vernier caliper, the photographs with a Canon Digital IXUS 65 camera.

In order to identify the mandible fragment, comparative material was used from several collections in addition to published data. We studied material at NCB Naturalis, Natuurhistorisch Museum Rotterdam and the Laboratory of Paleontology (Department of Geology, Aristotle University of Thessaloniki) (see Table 1), and used published data from Del Campana (1913), Kerkhoff (1992), Rook (1993), Baryshnikov \& Tsoukala (2010) and Baryshnikov (2012).
Table 1. Measurements for RGM631800.

\begin{tabular}{lc}
\hline Distance & Measurement (mm) \\
\hline Mandibular width below p1 & 12.0 \\
Mandibular height below p1 & 21.7 \\
Mandibular width below p2 & 12.0 \\
Mandibular height below p2 & 24.2 \\
Length of diastema & 7.3 \\
Length of canine at alveolus & 11.8 \\
Width of canine at alveolus & 7.0 \\
Length of p1 & 5.0 \\
Width of p1 & 4.4 \\
Length of p2 & 12.5 \\
Width of p2 & 6.0 \\
\hline
\end{tabular}

\section{Systematic palaeontology}

ORDER Carnivora Bowdich, 1821

FAMILY Canidae Fischer von Waldheim, 1817

TRIBE Canini Fischer von Waldheim, 1817

GENUS Canis Linnaeus, 1758

Canis cf. C. etruscus Forsyth-Major, 1877

Material: RGM631800 (Fig. 1).

Locality: 0osterschelde (Zeeland, the Netherlands).

Age: Early Pleistocene (c. 2.4-2.08 Ma).

Description: This partial mandible has two complete premolars (p1 and p2), the anterior part of p3 and the canine (c), which is broken on the level of the alveolus. Moreover, the ramus 
is broken at the level of the canine on the anterior side and obliquely at the level of $\mathrm{p} 3$ on the posterior side. The rest of it is complete. The p1 is small and peg-like, and possesses one root. The p2 has a triangular shape in lateral view, with the major cusp (protoconid) situated at about two-fifths from the anterior. The posterior part of $\mathrm{p} 2$ has a ridge that ends in a hook shape without bearing a clear cuspid; the tooth has two roots. In occlusal view, it has the greatest width at the posterior half. There is one mental foramen beneath the anterior root of $\mathrm{p} 2$. The measurements of this specimen are given in Table 1.

Comparison: Unfortunately, our mandible only possesses premolars, which usually show intraspecific variability in their morphology and are therefore somewhat less diagnostic. The studied mandible fragment points to a robust large-sized canid. The basic difference between $C$. lupus, $C$. familiaris and the subgenus Canis (Xenocyon) is that these three taxa have one extra cuspid on p2, situated somewhat above the lower part of its posterior end. Similarities in the dental morphology exist with C. arnensis, C. etruscus, C. apolloniensis and C. mosbachensis. However, there is a significant size difference with the smallsized $C$. arnensis and $C$. apolloniensis, which is indicated not only by the dentition, but also by measurements of the ramus. Moreover, $\mathrm{p} 1$ of $\mathrm{C}$. arnensis and $\mathrm{C}$. apolloniensis are more elongated (length $>>$ width) when compared to the $\mathrm{p} 1$ of $C$. etruscus and $C$. mosbachensis, which tend to be more semicircular (length $>$ width). In addition, the small-sized specimens are considerably more slender than RGM631800.

Cherin et al. (2013) published a revised diagnosis for the species $C$. etruscus. Most characteristics concern the skull and the upper dentition. Of the lower dental features mentioned in the revised diagnosis ('Lower dentition characterized by larger dimensions in respect to $C$. arnensis and by a wolf-like $\mathrm{m} 1 / \mathrm{m} 2$ ratio. The lower carnassial [m1] is distinguished by main trigonid cusps [protoconid and paraconid] relatively small [in comparison with C. lupus] and by talonid cusps [hypoconid and entoconid] linked by a sinous crest') only the size can be used to compare our fragment. Nevertheless, all available characters point either to $C$. etruscus or to the only slightly smaller but (according to Brugal \& Boudadi-Maligne, 2011) conspecific $C$. mosbachensis. The dental dimensions show our mandible to be closer to $C$. etruscus. Moreover, the height and width of the ramus measurements also indicate a close relation to $C$. etruscus. Because of the presence of only the less diagnostic premolars, we tentatively attribute mandible fragment RGM631800 to Canis cf. C. etruscus.

\section{Discussion}

Brugal \& Boudadi-Maligne (2011) recently revised and simplified the taxonomy of the Pleistocene members of the genus Canis by the recognition of only two species: (1) the smallsized $C$. arnensis (of which $C$. accitanus and C. apolloniensis are considered synonyms) and (2) the large-sized $C$. etruscus (which includes $C$. mosbachensis). This revision is mainly based on the fact that the two species groups are morphologically similar, differing only in size and size variability, which is not a factor of phyletic differentiation. By accepting this revision, the examination of our material indicates an identification as C. etruscus. The length of $\mathrm{p} 1$ falls in the $C$. arnensis group, although due to the length-width difference mentioned above, it has a closer morphologic relation to $C$. etruscus. In the case of $\mathrm{p} 2$, its size seems to fall in the $C$. etruscus group, with the $C$. arnensis group showing a clear overlap, although the latter is generally somewhat smaller. Again, the intraspecific variability of the premolars hampers a more precise conclusion.

The mandible represents the oldest find of the genus Canis in the Netherlands and surrounding regions of northwestern Europe. The fauna of the 0osterschelde of which it forms part is considered to have an age of about 2.35-2.10 Ma (De Vos et al., 1998; Scager, 2015), although it is recovered from sediments dating to c. 30 ka due to resedimentation (Slupik et al., 2013). The age of the jaw fragment is supposedly 2.35-2.10 Ma and so it predates the published ages of the 'Wolf Event', which is supposed to have occurred during the early Pleistocene late Villafranchian, around 1.9-1.8 Ma ago (Azzaroli, 1983; Azzaroli et al., 1988; Sardella \& Palombo, 2007) or even around $1.4 \mathrm{Ma}$ (e.g. Bonifay, 1990). Along with a small-sized jackal-like Canis in the Mediterranean region (C. arnensis) appeared a larger wolflike form, $C$. etruscus in the rest of the European continent. Younger forms of this taxon (often named C. mosbachensis) later gave rise to the wolf $C$. lupus (Garrido \& Arribas, 2008).

Other evidence seems to suggest, however, that the genus Canis first appeared in Europe as early as the Late Miocene (c. 7 $\mathrm{Ma}$ ) in the Teruel Basin, eastern Spain (C. cipio, see Pons-Moya \& Crusafont Pairo, 1978; Sotnikova \& Rook, 2010). C. cipio is still a questionable taxon due to its scarce record, as only one fragmented maxilla and an isolated tooth were found; it is suggested not to belong to the genus Canis sensu stricto (Sotnikova \& Rook, 2010). Another and more reliable early appearance of Canis (Canis sp.) is recorded from the site of Vialette, France, consisting of three fragmented mandibles, two isolated teeth and one tibia to which was attributed an age of c. 3.1 Ma (Lacombat et al., 2008). A canid (C. senezensis) was reported from from Senèze, France, dated to c. 2.0 Ma (Martin, 1973; Roger et al., 2000) and a small canid (C. accitanus) from southern Spain, dated to c. 1.9 Ma (Garrido \& Arribas, 2008); both localities are slightly younger than the 2.35-2.18 Ma Oosterschelde find.

Looking back into the history of the early canids, it is clear that the story of the Canis lineage is complicated, especially in Europe. Because the attribution of $C$. cipio from the Late Miocene in Spain ( $7 \mathrm{Ma}$ ) to the genus Canis is doubted, the most probable hypothesis would be to situate the origin of the genus in North America at around $4 \mathrm{Ma}$, with its first appearance in Asia (East China) dated around $3.4 \mathrm{Ma}$ 
(Flynn et al., 1991). Since the first accepted European Canini are dated around 3.1 Ma, it seems logical to conclude that Canis dispersed through Eurasia gradually and not instantaneously, and also much earlier than the Villafranchian. This confirms the doubts about the usefulness of the WE. The initial idea of this hypothesis was that the dispersal of Canis in Europe was accomplished in a short time interval, somewhere during the Villafranchian. We suggest here, following the suggestions of Rook \& Martínez-Navarro (2010) and Sotnikova \& Rook (2010), that this dispersal lasted longer and must have been diachronous, hence not an 'event' but rather a process. It is not useful as a biostratigraphical marker.

It is also worth noting that the 0osterschelde find expands the geographical range of the genus Canis up to the edge of northwestern Europe, as the record until now spanned only up to central Europe (Brugal \& Boudadi-Maligne, 2011). This shows that the spatial dispersal of Canini was greater than currently believed.

\section{Conclusion}

The discovery of a Canis cf. C. etruscus mandible at the 0osterschelde locality (Zeeland, the Netherlands) shows that the genus Canis was dispersed up to northwestern Europe already sometime before $2 \mathrm{Ma}$, which expands its previously known geographical range. In addition, we agree that the so-called 'Wolf Event' cannot be used as a biochronological marker as the dispersal of the Canini through Eurasia occurred before this event and took place diachronously.

\section{Acknowledgements}

We thank the Schot family and the crew of the vessel ZZ10 for organising and managing the annual trawling trip in search of fossils. We thank Hans-Jorg Ahrens and Reinier van Zelst (NCB Naturalis, Leiden) for letting us study the mandible and giving us access to the collection of Naturalis. Professors Dimitris Kostopoulos and George Koufos (Laboratory of Paleontology, Aristotle University of Thessaloniki) are thanked for access to the Canis material stored in Thessaloniki. Wilma Wessels (Utrecht University) provided critical remarks, and reviewers Lorenzo Rook and John de Vos were of great help improving the initial manuscript.

\section{References}

Azzaroli, A., 1983. Quaternary mammals and the 'end-Villafranchian' dispersal event - A turning point in the history of Eurasia. Palaeogeography, Palaeoclimatology, Palaeoecology 44: 117-139.

Azzaroli, A., de Giuli, C., Ficcarelli, G. \& Torre, D., 1988. Late Pliocene to Early Mid-Pleistocene mammals in Eurasia: Faunal succession and dispersal events. Palaeogeography, Palaeoclimatology, Palaeoecology 66: 77-100.
Baryshnikov, G.F., 2012. Pleistocene Canidae (Mammalia, Carnivora) from the Paleolithic Kudaro caves in the Caucasus. Russian Journal of Theriology 11: 77-120.

Baryshnikov, G.F. \& Tsoukala, E., 2010. New analysis of the Pleistocene carnivores from Petralona Cave (Macedonia, Greece) based on the Collection of the Thessaloniki Aristotle University. Geobios 43: 389-402.

Bonifay, M.-F., 1990. Relations between paleoclimatology and Plio-Pleistocene biostratigraphic data in West European countries. In: Lindsay, E.H. et al. (eds): European Neogene Mammal Chronology. Plenum Press (new York): 475485.

Brugal, J.-P. \& Boudadi-Maligne, M., 2011. Quaternary small to large canids in Europe: Taxonomic status and biochronological contribution. Quaternary International 243: 171-182.

Cherin, M., Bertè, D.F., Rook, L. \& Sardella, R., 2013. Re-defining Canis etruscus (Canidae, Mammalia): A new look into the evolutionary history of Early Pleistocene dogs resulting from the outstanding fossil record from Pantalla (Italy). Journal of Mammalian Evolution 21: 95-110.

Del Campana, D., 1913. I cani Pliocenici di Toscana. Palaeontographica Italica 19: 192-254.

De Vos, J., Mol, D. \& Reumer, J.W.F. 1998. Early Pleistocene mammalian remains from the Oosterschelde or Eastern Scheldt (province of Zeeland, the Netherlands). In: Van Kolfschoten, T. \& Gibbard, P.L. (eds): The Dawn of the Quaternary: Proceedings of the SEQS-EuroMam symposium, Kerkrade, 1996. Mededelingen Nederlands Instituut voor Toegepaste Geowetenschappen TNO (Utrecht): 60: 173-185.

Flynn, J.J., Tedford, R.H. \& Qiu, Z., 1991. Enrichment and stability in the Pliocene mammal faunas of North China. Paleobiology 17: 246-265.

Garrido, G. \& Arribas, A., 2008. Canis accitanus nov. sp., a new small dog (Canidae, Carnivora, Mammalia) from the Fonelas P-1 Plio-Pleistocene site (Guadix basin, Granada, Spain). Geobios 41: 751-761.

Kerkhoff, N.C., 1992. Hond of Wolf? Cranium 9: 89-104.

Lacombat, F., Abbazzi, L., Ferretti, M.P., Martínez-Navarro, B., Moullé, P.-E., Palombo, M.-R., Rook, L., Turner, A. \& Valli, A.M.F., 2008. New data on the Early Villafranchian fauna from Vialette (Haute-Loire, France) based on the collection of the Crozatier Museum (Le Puy-en-Velay, Haute-Loire, France). Quaternary International 179: 64-71.

Martin, $R .$, 1973. Trois nouvelles espèces de Caninae (Canidae, Carnivora) des gisements Plio-Villafranchiens d'Europe. Documents des Laboratoires de Géologie de Lyon 57: 87-96.

Mayhew, D.F., Dieleman, F.E., Slupik, A.A., van den Hoek Ostende, L.W. \& Reumer, J.W.F., 2014. Small mammal assemblages from the Quaternary succession at Moriaanshoofd (Zeeland, the Netherlands) and their significance for correlating the 0osterschelde fauna. Netherlands Journal of Geoscienses/Geologie en Mijnbouw 93(3): 119-134.

Mol, D., van den Bergh, G.D. \& de Vos, J., 1999. Fossil proboscideans from The Netherlands, the North Sea and the Oosterschelde Estuary. Deinsea 6: 119-146.

Palombo, M.R. \& Valli, A.M.F., 2003-2004. Remarks on the biochronology of mammalian faunal complexes from the Pliocene to the Middle Pleistocene in France. Geologica Romana 37: 145-163.

Pons Moya, J. \& Crusafont Pairo, M., 1978. El Canis cipio Crusafont (1950), comparación con los canidos del Plioceno y Pleistoceno europeo. Acta Geologica Hispanica 13(4): 133-136. 
Reumer, J.W.F., Mayhew, D.F. \& van Veen, J.C., 2005. Small mammals from the Late Pliocene 0osterschelde dredgings. Deinsea 11: 103-118.

Roger, S., Coulon, C., Thouveny, N., Féraud, G., Van Velzen, A., Fauquette, S., Cochemé, J.J., Prévot, M. \& Verosub, K.L., 2000. 40Ar/39Ar dating of a tephra layer in the Pliocene Senèze maar lacustrine sequence (French Massif Central): constraint on the age of the Reunion-Matuyama transition and implications on paleoenvironmental archives. Earth and Planetary Science Letters 183: 431-440.

Rook, L., 1993. I Cani dell'Eurasia dal Miocene superiore al Pleistocene medio. Unpublished $\mathrm{PhD}$ dissertation in palaeontological sciences. Universities of Modena (Bologna, Firenze and Roma).

Rook, L. \& Martínez-Navarro, B., 2010. Villafranchian: The long story of a PlioPleistocene European large mammal biochronologic unit. Quaternary International 219: 134-144.
Sardella, R. \& Palombo, M.R., 2007. The Pliocene-Pleistocene boundary: Which significance for the so called 'Wolf Event'? Evidence from Western Europe. Quaternaire 18(1): 65-71.

Scager, D.J., 2015. Kor \& Bot: 65 jaar en 2000 fossielen later. Een inventarisatie en interpretatie van de collectie. Cranium. 32(1): 6-18.

Slupik, A.A., Wesselingh, F.P., Mayhew, D.F., Janse, A.C., Dieleman, F.E., van Strydonck, M., Kiden, P., Burger, A.W. \& Reumer, J.W.F., 2013. The role of a proto-Schelde River in the genesis of the southwestern Netherlands, inferred from the Quaternary successions and fossils in Moriaanshoofd Borehole (Zeeland, the Netherlands). Netherlands Journal of Geosciences/Geologie en Mijnbouw 92(1): 69-86.

Sotnikova, M. \& Rook, L., 2010. Dispersal of the Canini (Mammalia, Canidae: Caninae) across Eurasia during the Late Miocene to Early Pleistocene. Quaternary International 212: 86-97. 